Click www.researchjournal.co.in/online/subdetail.html to purchase.

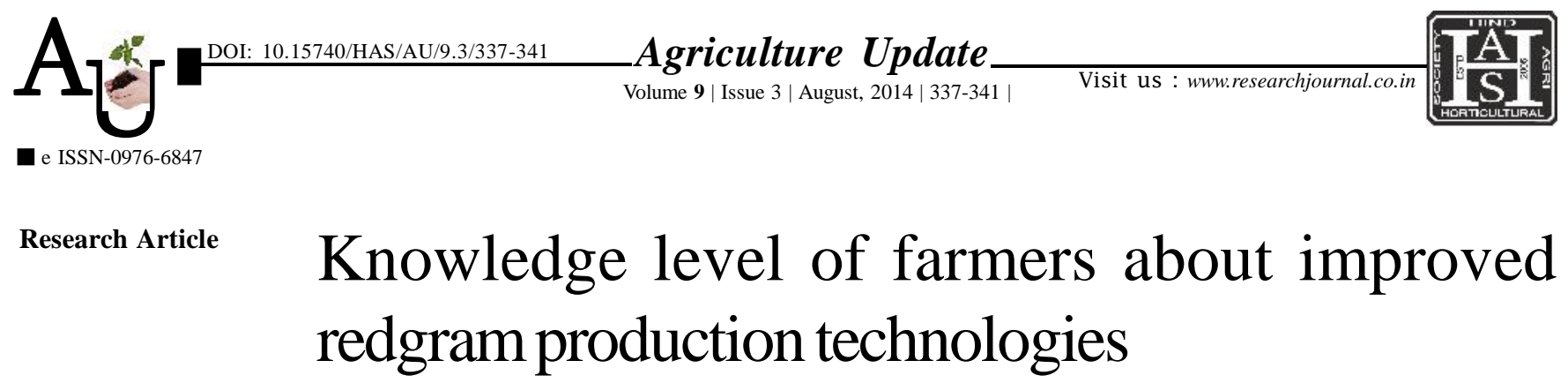

Article Chronicle: Summary : The research study was conducted in Bijapur district of Karnataka during the year 2013 with Received : 24.05.2014;

Revised : 09.06.2014; Accepted : 24.06.2014

KEY Words:

Adoption, Summer ploughing, Nipping, Micronutrients, IPM, Redgram, Improved production technologies

Author for correspondence :

\section{S.G. ASKI}

Department of Agricultural Extension Education, Agriculture College, BIJAPUR (KARNATAKA) INDIA

Email: askisubhash@ gmail.com

See end of the article for authors' affiliations sample size of 140 respondents. The findings revealed that, 37.14 per cent of trained and 21.43 per cent of untrained farmers belonged to high knowledge level category, while 40.00 per cent of trained and 34.29 per cent of untrained respondents belonged to medium knowledge level category, whereas 22.86 per cent of trained and 44.28 per cent of untrained respondents were belonged to low knowledge level category. In case of variety 88.57 per cent of trained and 50.00 per cent of untrained respondents had knowledge about varieties like Maruti, TS3R, Asha, Pragati and PT-221 these are recommended for their region. Seed rate for sole red gram cultivation 97.14 per cent of trained and 92.86 per cent of untrained respondents had correct knowledge of seeds required for sowing of sole red gram for one acre. Whereas, 95.71 per cent of trained and 92.86 per cent of untrained respondents had knowledge about recommended seed rate for mixed crop of redgram.

How to cite this article : Jadhav, Kiran Kumar and Aski, S.G. (2014). Knowledge level of farmers about improved redgram production technologies. Agric. Update, 9(3): 337-341. 